\title{
Federal legislation to limit bulk drug exports
}

Published at www.cmaj.ca on June 30, 2005.

Health Minister Ujjal Dosanjh will introduce legislation this fall to amend the Food and Drugs Act, prohibiting the bulk export of pharmaceuticals from Canada when the federal government is aware of any shortages of prescription drugs or vaccines.

"It wouldn't be a permanent ban, it would be a ban only when there is a shortage in terms of our own supply," Dosanjh told a June 29 news conference in Ottawa.

The US Congress is considering 4 bills that would permit the import of lower-priced prescription drugs from Canada and other countries. These bills $\stackrel{\circ}{\circ}$ have prompted concerns in
Canada that a glut of American buyers could create shortages and force up prices.

Health Canada will establish a national database, known as the "drug supply network," to gather information about drug availability and shortages.

Dosanjh also announced plans to strengthen regulations in the Food and Drugs Act regarding the nature of the doctor-patient relationship. He would not say whether that means Americans seeking to save money by filling prescriptions in Canada would have to see Canadian doctors in person, or whether that relationship could consist of telephone calls or email communication. Health Canada will consult physician and pharmacist associations and other stakeholders before drafting legislation.

CMA President Dr. Albert Schumacher said, "This [consultation] is particularly important when it comes to defining key components of this issue, such as what constitutes an established patient-practitioner relationship."

The federal government does not intend to kill Canada's $\$ 1$ billion Internet pharmacy industry, Dosanjh said. - Laura Eggertson, CMAJ

\section{Privacy Issues}

\section{Gunshot wound reporting mandatory in Ontario}

Ontario's hospitals will soon assume the mantle of Neighbourhood Watch as the province follows the lead of 45 American states to become the first Canadian jurisdiction with manda- tory reporting of gunshot $\vec{\circ}$ wounds.

Under the legislation, passed May 31 and expected to be proclaimed by the fall, hospitals must designate someone responsible for promptly reporting to the police the name and hospital

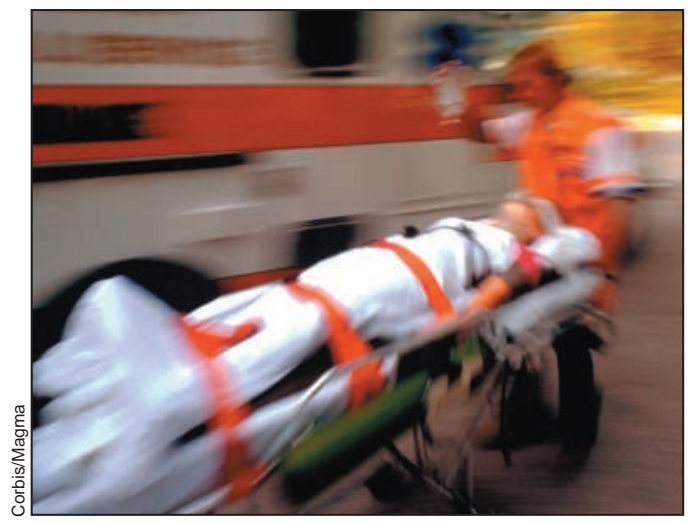

Proponents of mandatory gunshot wound reporting say it will reduce gun-related violence. location of patients who present with a gunshot wound.

However, there's no penalty for failing to disclose, and the government has no intention of introducing any form of censure, says Andrew Hilton, spokesman for Ontario Minister of Community Safety and Correctional Services Monte Kwinter. "The bill was never really designed to penalize people. The intent is to make it easier for hospitals to report gunshot wounds without fear of recrimination or any consequences for doing so."

Still, regulations may be introduced to extend the reporting requirement beyond hospitals, to clinics and doctors' offices "if it turns out... we're missing a lot," Hilton adds.

Opinion is divided over whether the legislation is a justified breach of doctor-patient confidentiality and trust (CMAJ 2004;170:1256-7 and 2004;170: 1255-6).

Proponents argue that compulsory reporting limits the risk of further injury and danger to the public, and that reporting data will better inform strategies to prevent similar incidents.

Opponents counter that mandatory reporting is a breach of doctor-patient confidentiality and trust, and that it may deter some patients from seeking treatment. They say education and safety training are more effective tools than mandatory reporting in preventing gunshot wounds.

Equally problematic is the question of the efficacy of mandatory reporting. University of Alberta Health Law Institute Executive Director Tracy Bailey says there's little concrete evidence indicating that mandatory gunshot wound reporting actually results in a reduction in gunrelated violence.

The legislation also raises ethical dilemmas for health professionals, because it places them in the position of becoming crime investigators, Bailey adds. "It's not their role. I'd be a lot more comfortable with discretionary reporting." - Wayne Kondro, Ottawa 